\title{
The size variation of rotifer Brachionus rotundiformis cultivated with different feed at $\mathbf{4 0}$ ppt salinity
}

\author{
Variasi ukuran rotifer Brachionus rotundiformis yang diberi pakan berbeda \\ pada salinitas $40 \mathrm{ppt}$ \\ Joice R.T.S.L Rimper, ${ }^{1 *}$ Silvana D. Harikedua, ${ }^{2}$ Veibe Warouw ${ }^{1}$ \\ ${ }^{1}$ Marine Science Study Program, Faculty of Fisheries and Marine Science, Sam Ratulangi University. \\ Jl. Kampus Unsrat Bahu, Manado 95115, North Sulawesi, Indonesia \\ ${ }^{2}$ Fishery Product Technology Study Program, Faculty of Fisheries and Marine Science, \\ Sam Ratulangi University, Manado, North Sulawesi, Indonesia \\ *Email: joice.rimper@unsrat.ac.id
}

\begin{abstract}
Rotifer Brachionus rotundiformis is a group of zooplankton which is used by fish larvae for feeding to initiate their growth. This zooplankton is widely favored by marine fauna larvae because of its small size can fits well with various larval mouth; thus, it is easily preyed by larvae. This study aimed to determine the variation of rotifer B. rotundiformis morphometry if cultured with different feed at $40 \mathrm{ppt}$. The use of $40 \mathrm{ppt}$ salinity is expected to provide a variable morphometric size because $B$. rotundiformis has a polymorphism property. Microalgae used as feed for rotifer B. rotundiformis were Prochloron sp. and Nanochloropsis oculata. Microalgae were cultured with Hirata medium. In the early stages, B. rotundiformis was cultured at optimum temperature $\left(28{ }^{\circ} \mathrm{C}\right)$ and salinity $20 \mathrm{ppt}$, then it was cultured at salinity $40 \mathrm{ppt}$. Salinity adaptation was done by raising the salinity of the medium by 2 ppt every two days in a $10 \mathrm{ml}$ reaction tube containing 10 individuals. After adaptation, $B$. rotundiformis was transferred in a $1000 \mathrm{ml}$ container with a density of 50 individuals. For the morphometric aspect, the total length, the length of the lorica, the width of the lorica and the anterior width were measured. The result showed the morphometric of rotifer B. rotundiformis fed with microalgae Prochloron sp. at $40 \mathrm{ppt}$ salinity was smaller than that of the rotifer fed with $N$. oculata. Based on that finding it can be concluded that $B$. rotundiformis fed with Prochloron sp. at a salinity of $40 \mathrm{ppt}$ has the potential to be developed as feed for fish larvae. Further investigations on how to accelerate the cultivation of microalgae Prochloron sp. as feeding for $B$. rotundiformis are needed.
\end{abstract}

Keywords: rotifer; Brachionus rotundiformis; fish larvae; polymorphism; marine algae.

Abstrak: Rotifer Brachionus rotundiformis merupakan golongan zooplankton yang digunakan sebagai makanan bagi larva ikan. Zooplankton ini banyak disukai oleh larva fauna laut, karena ukurannya kecil yang cocok dengan berbagai bukaan mulut larva. Penelitian ini bertujuan untuk mengetahui variasi morfometri rotifer $B$. rotundiformis, jika dikultur pada salinitas yang tinggi (40 ppt) dengan pemberian pakan berbeda. Penggunaan salinitas 40 ppt diharapkan bisa memberikan ukuran morfometrik yang bervariasi, karena rotifer jenis ini memiliki sifat polimorfisme. Alga mikro yang digunakan sebagai pakan adalah Prochloron sp. Dan Nanochloropsis oculata. Alga mikro tersebut dikultur dalam media Hirata. Pada tahap awal, B. rotundiformis dikultur pada suhu optimum $\left(28^{\circ} \mathrm{C}\right)$ dengan salinitas $20 \mathrm{ppt}$; kemudian, dikultur pada salinitas $40 \mathrm{ppt}$. Adaptasi salinitas dilakukan dengan menaikkan salinitas medium sebanyak 2 ppt setiap dua hari dalam tabung reaksi berukuran $10 \mathrm{ml}$, yang berisi 10 individu. Setelah diadaptasikan, rotifer dipindahkan ke wadah berukuran 1000 $\mathrm{ml}$ dengan kepadatan sebanyak 50 individu dan dikultur pada salinitas 40 ppt. Aspek morfometri berupa panjang total, panjang lorica, lebar lorica, dan lebar anterior diukur. Hasil penelitian menunjukkan, bahwa panjang total rotifer B. rotundiformis, yang diberi pakan Prochloron sp. berukuran lebih kecil dibandingkan dengan rotifer yang diberi pakan $N$. oculata. Berdasarkan hasil penelitian dapat disimpulkan, bahwa B. rotundiformis yang diberi pakan Prochloron sp. pada salinitas 40 ppt memiliki potensi untuk dikembangkan sebagai bahan pakan bagi larva ikan. Penelitian lebih lanjut tentang cara mempercepat budidaya microalgae Prochloron sp. sebagai makan untuk $B$. rotundiformis diperlukan.

Kata-kata kunci: rotifer; Brachionus rotundiformis; larva ikan; polymorfisme; alga laut.

\section{INTRODUCTION}

The ocean hidden enormous natural resources that can be exploited with responsibility for human welfare. Marine potency resides not only on macro organism but also on micbiological potential is not only a macroorganism, but also a microorganism. Plankton has two functions in the marine food chain 
as a primary and secondary producer. Some zooplankton have been widely used as live feed for larvae, namely rotifer Brachionus rotundiformis (Rumengan, 1997). Rotifer B. rotundiformis has the potential to be developed for the feeding of fish larvae in its early stage (Fieder and Purser, 2000; Assavaaree et al., 2001). Rotifer B. rotundiformis is favored by a variety of marine fauna larvae because it is a relatively small in size and suitable for larvae mouth. Due to the rotifer characteristics, it is suggested that rotifer could be cultivated as natural food for fish larvae. In an attempt to identify the possibility of cultivating rotifer in a laboratory, this study aimed to determine the variation of rotifer morphometric size cultured with different feed and high salinity at $40 \mathrm{ppt}$.

In this study, microalgae used as feed for rotifer B. rotundiformis were Prochloron sp. and $N$. oculata. Microalgae $N$. oculata is one of the most popular feed for culture rotifer in Japan (Maruyama, et al., 1986; Maruyama and Hirayama, 1993) while Prochloron sp. is a newly tested feed. Recent study from Ogello et al. (2017) discovered that dried microorganisms of $N$. oculata and Chlorella vulgaris can accelerate the growth of rotifer $B$. rotundiformis. Rimper et al. (2008) succesfully showed $B$. rotundiformis can be cultured with microalgae N. oculata and Prochloron sp. at $20 \mathrm{ppt}$ salinity. This finding revealed that microalgae Prochloron sp. has smaller morphometry than $N$. oculata. Therefore, the objective of this study was to determine the variation of rotifer morphometric size cultured with different feed at higher salinity (40 ppt). The hypothesis is that higher salinity treatment will result in a different morphometry. It is expected that $40 \mathrm{ppt}$ salinity treatment could provide a various morphometric size because $B$. rotundiformis has a polymorphism property. Polymorphism is a symptom when an organism changes in shape and size of lorica if the environmental conditions alter (Nogrady et al., 1993).

\section{MATERIALS AND METHODS}

The study was conducted in Marine Biotechnology, Marine Biology, and Chemical Laboratory, Faculty of Fisheries and Marine Sciences, Sam Ratulangi University of Manado. Microalgae used for feeding the rotifers were $N$. oculata and Prochloron sp. with a density of $3 \times 10^{6}$ cells $/ \mathrm{ml}$. Microalgae were cultured in Hirata medium (Hirata, 1975). The culture container was equipped with an aerator to promote algal growth. The algae incubator had 20 watt lamps as source of light for algae. The room was set at $25^{\circ} \mathrm{C}$. The microalgae used for feeding $B$. rotundiformis was centrifuged and the precipitate was stored in the refrigerator as feed stock. $B$. rotundiformis was cultured in a $1000 \mathrm{ml}$ container. In the early stages, $B$. rotundiformis was cultured at optimum temperature $\left(28^{\circ} \mathrm{C}\right)$ and salinity $(20 \mathrm{ppt})$. Furthermore, B. rotundiformis was adapted at 40 ppt salinity. The seawater was boiled about two hours and cooled to increase the salinity. The water was measured with a refractometer until a salinity of $40 \mathrm{ppt}$ was obtained. The adaptation of $B$. rotundiformis in different salinity was done by raising the salinity of the medium 2 ppt every two days in a $10 \mathrm{~mL}$ reaction tube containing 10 individuals. After adaptation, B. rotundiformis was transferred into a $1000 \mathrm{~mL}$ container with a density of 50 individuals and cultured at $40 \mathrm{ppt}$ salinity with two different feed types ( $N$. oculata and Prochloron sp.).

The morphometric measurements were based on three parts, namely the length of the lorica (LL), the width of the lorica (WL) and the anterior width (AW) (Hagiwara et al., 1995).

\section{RESULTS}

The study demonstrated that there are higher variations of rotifer $B$. rotundiformis morphometry with different feed treatment and cultivated at 40 ppt salinity. The mean value based on morphometry measurement on rotifer fed with $N$. oculata was: Total length $(\mathrm{TL})=221 \mu \mathrm{m}$; Length of Lorika (LL) $=137.98 \mu \mathrm{m}$; Anterior width $(\mathrm{AW})=68.85 \mu \mathrm{m}$; Lorika's width $(\mathrm{LW})=109.65 \mu \mathrm{m}$. Meanwhile, the morphometry of rotifer fed with Prochloron sp. were: Total Length $(\mathrm{TL})=157.70 \mu \mathrm{m}$; Length of Lorika $(\mathrm{LL})=120,63$; Anterior Wide $(\mathrm{AW})=$ 56.16; Lorika's width $(\mathrm{LW})=96.83 \mu \mathrm{m}$ (Figure 1). Apparently, the morphometric of rotifer $B$. rotundiformis fed with microalgae Prochloron sp. at $40 \mathrm{ppt}$ salinity was smaller than that of the rotifer fed with $N$. oculata.

\section{DISCUSSION}

The study showed that the smallest rotifer $B$. rotundiformis morphometry was found in rotifer fed with Prochloron sp. This phenomenon was likely due to the polymorphism of rotifer $B$. rotundiformis. Polymorphism was the condition where shape and size of the lorika undergoing changes to a kind of plasticity if the environmental conditions 


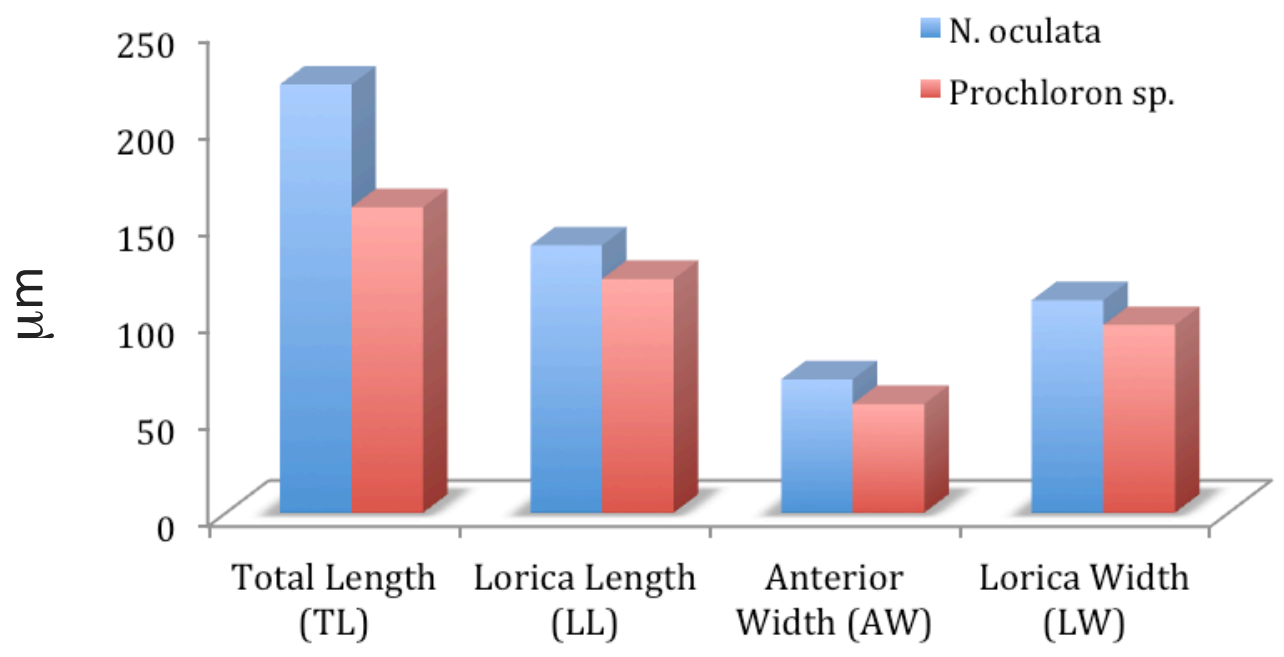

Figure 1. Morphometric length $(\mu \mathrm{m})$ of rotifer Brachionus rotundiformis fed with microalgae Nanochloropsis oculata and Prochloron sp. at 40 ppt salinity

transformed (Nogrady et al., 1993). This polymorphism can lead to a considerable difference of $15 \%$ morphometric (Fukusho, 1989).

The results showed that feeding Prochloron sp. to $B$. rotudinformis resulting in a smaller morphometric size when compared to $N$. oculata feed. This result was expected. Moreover, this result demonstrated that this situation could be beneficial since marine biologist could manipulate the development of $B$. rotudiformis as a natural feed that fits different sizes of fish larval mouth.

\section{CONCLUSION}

The morphometric of rotifer B. rotundiformis fed with microalgae Prochloron sp. at 40 ppt salinity was smaller than that of the rotifer fed with $N$. oculata. Further investigations on how to accelerate the cultivation of microalgae Prochloron sp. as feeding for $B$. rotundiformis are needed.

\section{REFERENCES}

ASSAVAAREE, M., HAGIWARA, A. and LUBZENS, E. (2001) Factor affecting low temperature preservation of the marine rotifer Brachionus rotundiformis Tschugunoff. Hydrobiologia, 446-447, 355-361.

FIEDER, D.S. and PURSER, G.J. (2000) Effect of rapid changes in temperature and salinity on availability of the rotifers Brachionus rotundiformis and Brachionus plicatilis. Aquaculture, 189, 85-99.

FUKUSHO, K. (1989) Biology and mass production of the rotifer Brachionus plicatilis. Int. J. Aq. Fish. Technol., 1, 232-240.

HAGIWARA, A., KOTANI, T., SNELL, T.W., ASSAVAREE, A.M. and HIRAYAMA, K. (1995) Morphology reproduction, genetics and mating behavior of small tropical marine Brachionus Strain. Journal of Marine Biology and Ecology, 194, 25-37.

HIRATA, H. (1975) Preliminary Report on The Photoperiodic Acclimation for Growth of Chlorella Cells in Syncronized Culture. Japan: Kagoshima University.

MARUYAMA, I. and HIRAYAMA, K. 1993. The culture of the rotifer Brachionus plicatilis with Chlorella vulgaris containing vitamin B12 in its cells. J. World Aquac. Soc., 24, 194-198.

MARUYAMA, I.T., NAKAMURA, T., MATSUBAYASHI, Y., ANDO and MAEDA, T. (1986) Identification of the algae known as marine Chlorela as a member of the eustig mathophyceae. Jap. J. Phycol., 34, 312-325.

NOGRADY, T., WALLACE, R.L. and SNEEL, T.W. 1993. Rotifer, Biology, Ecology and Systematic. Volume 2. Netherland: Academic Publishing.

OGELLO, E., SAKAKURA, O.Y. and HAGIWARA, A. (2017) Culturing Brachionus rotundiformis Tschugunoff (Rotifera) using dried foods: application of gammaaminobutyric acid (GABA). Hydrobiologia, 112. 
Rimper et al.: The size variation of rotifer Brachionus rotundiformis cultivated with different ...

RIMPER, J., KASWADJI, R., WIDIGDO, B., SUGIRI, N. and RUMENGAN, I.F.M. (2008) Body size of rotifers (Brachionus rotundiformis) from estuaries in North Sulawesi. Marine Finfish Aquaculture Network, XIII (I).
RUMENGAN, I.F.M. (1997) Rotifer laut (Brachionus spp.) sebagai bio kapsul bagi larva berbagai jenis fauna laut. Warta Wanita Ilmu Pengetahuan dan Teknologi, 19, 5-10.

Received: 3 March 2019 Accepted: 25 April 2019 